\title{
An analysis of productivity app strengths: An environmental scan
}

Aug 24, 2021

Harshdeep Dhaliwal, ${ }^{1}$ Kundan Ahluwalia, ${ }^{1}$ Dana Kukje Zada, ${ }^{1}$ Daphne Qin, ${ }^{1}$ Rameen Tanveer, ${ }^{2}$ Julianna Botros ${ }^{1}$, Joy $\mathrm{Xu}^{1}$

${ }^{1}$ McMaster University, Hamilton, ON, Canada

${ }^{2}$ Lakehead University, Thunder Bay, ON, Canada

Contact Info: harshdeep569340@gmail.com

\begin{abstract}
Background

In recent years, productivity apps have become the most commonly used apps. While some may feel productivity apps work solely as a result of the placebo effect, productivity apps have been shown to have three major benefits: accountability, assessment, and improvement. Stress levels were especially reduced in the two meditation groups as opposed to the muscle relaxation group . Furthermore, there has been reported evidence on the effectiveness of app-based meditation and mindfulness in reducing stress and increasing productivity for users.

Methods

In order to answer the research question, published articles from ProQuest, Business Source Premier and Web of Science were used. Additionally, Harvard Business Review was also used as a source of grey literature. Information was collected in order to determine the strengths of competing productivity apps and how they could limit or be applied to the Felicity App. The research was reviewed based on screening tools that assessed validity and relevance. Included studies were published within Asia, North America, Australia, or Europe, and where either quantitative, qualitative, randomized controlled trial (RCT), surveys, experiments with participants, or academic studies. Study screening and extraction were completed independently among two authors. Disagreements following reconciliation between the two authors were settled by a third author.
\end{abstract}

Results

The selected articles discuss information including methods of improving productivity, mobilebased interventions that are effective at improving either overall health or productivity, and techniques that may be applicable to the Felicity App as a mobile-based intervention.

Conclusion

The results show that the Felicity App can improve user outcomes by integrating features from other applications.

Keywords

productivity apps AND mobile 


\section{INTRODUCTION}

In recent years, productivity apps have become the most commonly used apps. In a 2019 survey, 496 participants reported their app usage. The survey revealed that productivity apps scored highest in terms of usage for $96.77 \%$ of participants [20]. "Productivity app" is an umbrella term for any software that increases efficiency and boosts productivity. The term has come to take on several iterations - from applications that decrease the amount of time it takes to complete a task by making the process more efficient, as well as applications that encourage individuals to increase their output while completing a task. Therefore, this environmental scan aims to analyze the current 'market' for productivity apps. Based on these findings, the strengths and areas of improvements of the Felicity App were analyzed. The Felicity App is a mobile productivity application which provides psychological interventions to young adults (15 to 40 years old). A comparison of our app-based interventions with other interventions will be done in this systematic review to answer the question: "How can the strengths of competing productivity apps limit or be applied to the Felicity App?"

To answer the research question, it is important to first consider the effectiveness of mobile app interventions to increase users' productivity. Over the course of time, many branding companies have claimed that their app will help individuals become more productive, organized and help them manage their time better. However, are these claims based on evidence or simply speculation? Research suggests that productivity apps can increase efficiency by more than $34 \%$ [1]. On the simplest level, productivity apps work by helping individuals see how much they work, when they work and what they spend their time working on. While some may feel productivity apps work solely as a result of the placebo effect (one tells themself they are being productive, and in turn they are), productivity apps have been shown to have three major benefits: accountability, assessment, and improvement.

When looking at accountability, productivity apps use tactics such as visualizations to help hold users to their goals of completing tasks that encourage and motivate them to keep going. In addition, with increasing levels of motivation, individuals are less likely to become distracted by minor things that can hinder their progress in completing tasks. For example, research surveys reveal that productivity decreases by $34 \%$ when working in a distracting environment [7]. Similarly, productivity apps can aid in helping individuals create personal assessments. These assessments can be centered around the way they are using their time and how long certain tasks take. From these assessments, when individuals are aware of the way in which they spend their time, they can take the necessary steps towards making a change. Lastly, a large benefit of productivity apps are making progress towards improvement. When individuals download such apps, they are likely interested in making a change and feel that these apps will help them reach this desired change. 
Although productivity apps are getting increasingly similar in their functions, the Felicity App introduces novel mechanisms through an online medium to aid in productivity. This is done through great emphasis on emotional regulation, mindfulness and meditation which have all been shown to be correlated with increasing productivity. Therefore, Carrington et al conducted a study whereby the effect of mantra meditation, respiratory meditation and muscle relaxation were studied on stress levels in a cohort of 154 working young adults. Participants who followed one of these three strategies for approximately 6 months exhibited a significant reduction in stress levels. Stress levels were especially reduced in the two meditation groups as opposed to the muscle relaxation group [3]. Furthermore, there has been reported evidence on the effectiveness of app-based meditation and mindfulness in reducing stress and increasing productivity for users. An example of this is seen in a study conducted by Lindsay et al., which studied the use of app/mobile-based meditation on stress reduction in a cohort of 153 adults experiencing stress. The study emphasizes that the highest reduction in cortisol levels was observed when mindfulness and acceptance training were used in conjunction to alleviate stress. These findings are promising and support the science behind many of the interventions implemented in the Felicity App speaking to the strength of the upcoming app [8]. Stress reduction has been extensively correlated with increased productivity as it allows individuals to concentrate on their task and complete it efficiently. For example, Krishanamacharyulu et al administered a questionnaire to participants where they scored their learning capacity, emotional regulation and ability to organize their time before and after completing a daily 30 minute meditation twice a day. The study showed that participants were able to significantly improve their time management, learning capacity and emotional regulation by the end of the study [23]. Altogether, this data shows that mindfulness practices have a significant effect on stress reduction which in turn allows for increased productivity. This knowledge in conjunction with the proven success and effectiveness of mindfulness mobile apps highlights the strength of the Felicity App as it focuses on several mindfulness interventions to maximize user productivity and wellbeing.

The focus on productivity in the modern world has created a demand for productivity apps which push users to work more efficiently. Optimizing user's productivity is the primary goal of the Felicity App which introduces evidence-based interventions for time-management, procrastination, motivation, well being and psychological capital. Although the use of interventions and psychological concepts grounded in literature makes this application very promising, there are some areas of improvements that can be focused on. Therefore, this environmental scan will answer the question: "How can the strengths of competing productivity apps limit or be applied to the Felicity App?" to maximize the success and efficiency of the Felicity App. 


\section{METHODS}

To determine the strengths of competing productivity apps and how they could limit or be applied to the Felicity App, an environmental scan was conducted. The aim of this environmental scan was to analyze current circulating productivity apps through existing literature to help ensure the user enhancement of productivity with the Felicity App. This scan was conducted with the Preferred Reporting Items for Systematic Review and Meta-Analyses (PRISMA) guidelines.

Study design \& setting

This environmental scan investigated the strengths of competing productivity apps and how they could possibly limit or be applied to the Felicity App. The Felicity App is a mobile application aiming to increase the productivity of students and workers with psychological interventions. This is imperative as it can increase the success of students and workers. Essentially, students can retain academic goals, while workers can retain career/financial goals, by increasing productivity. Considering harrowing productivity statistics, it is vital to increase productivity. For example, the average employee is productive for less than 3 hours per day [2]. This not only costs employers billions of dollars in lost revenue, but it also restricts the retaining of career/financial goals by workers. By studying the strengths of current circulating productivity apps, certain qualities can be incorporated into the Felicity App and used to boost productivity.

A mixed-method study design was used to evaluate both qualitative and quantitative information [9]. Qualitative data determined which qualities of an application enhanced the productivity of their users (such as potentially increasing the number of reminder notifications sent to users, etc.) and whether those strengths could be integrated into the Felicity App . Quantitative data provided measurable results identifying patterns or trends regarding the certain strengths of a productivity app and the corresponding productivity of the user. Through a convergent synthesis integration approach in analyzing the data, all types of data were covered to provide an in depth systematic review of the research question.

\section{Search strategy \& criteria}

The different kinds of literature (such as both published and unpublished studies based on the eligibility criteria of this study) were reviewed. The Preferred Reporting Items for Systematic Reviews and Meta-Analysis Protocol (PRISMA- P) guideline was used to confirm the scientific accuracy.

An experienced information specialist searched Web of Science, Business Source Premier, and ProQuest for the period of January 1992 to December 2020. To ensure finding all relevant studies on this topic a broad range of synonyms were used for the search (see Appendix 1 for the search strategy). For the grey implementation-focused literature, a search for documents in the Harvard Business Review was conducted. Also, using Google and Google Scholar, the 
snowballing method was used to identify additional sources from references cited in various fact sheets, conference proceedings, and book chapters (refer to Appendix 2).

\section{Information Sources and Searches}

Based on the eligibility criteria of this study, various forms of literature were reviewed including peer-reviewed and grey literature. Searches in databases (Web of Science, Business Source Premier, and ProQuest) were conducted by researchers from June 6, 2021 to June 15, 2021. Studies were limited to the publication period between January 1992 to Present Day. Searches utilized keywords for procrastination, motivation, psychological capital, time management, and well-being, as well as overall productivity. To optimize relevance of topics within studies, various keywords were customized for the search (refer to Appendix 1.).

For grey implementation-focused literature, a search for documents was conducted from the Harvard Business Review (HBR). The Harvard Business Review is a general management magazine published by Harvard Business Publishing which covers a wide range of topics that are relevant to various industries, management functions, and geographic locations. These divisions include subtopics such as leadership, operations, marketing and finance. Documents found within each grey-implementation literature database were subjected to the same inclusion/exclusion criteria and research question as studies found within Web of Science, Business Source Premier, and ProQuest. Grey literature sources were preferentially selected from NGO (non-governmental organization) websites and IGO (international governmental organization) websites to enhance validity.

\section{Inclusion \& exclusion}

The inclusion and exclusion criteria for this study were predetermined. Studies were only included if written in English, psychology-based, and published between 1992 - 2020. Eligible study designs included randomized controlled trials, meta-analysis, systematic reviews, and grey literature. Studies were deemed suitable if the studied demographic consists of human subjects between the ages of 15 to 40 that were not diagnosed with any medical complications. Studies consisted of both genders residing in developed countries. Furthermore, studies were only included if strategies and concepts were directly applied or could be manipulated for usage in a virtual setting. Fig. 1 depicts the SPIDER analysis. 


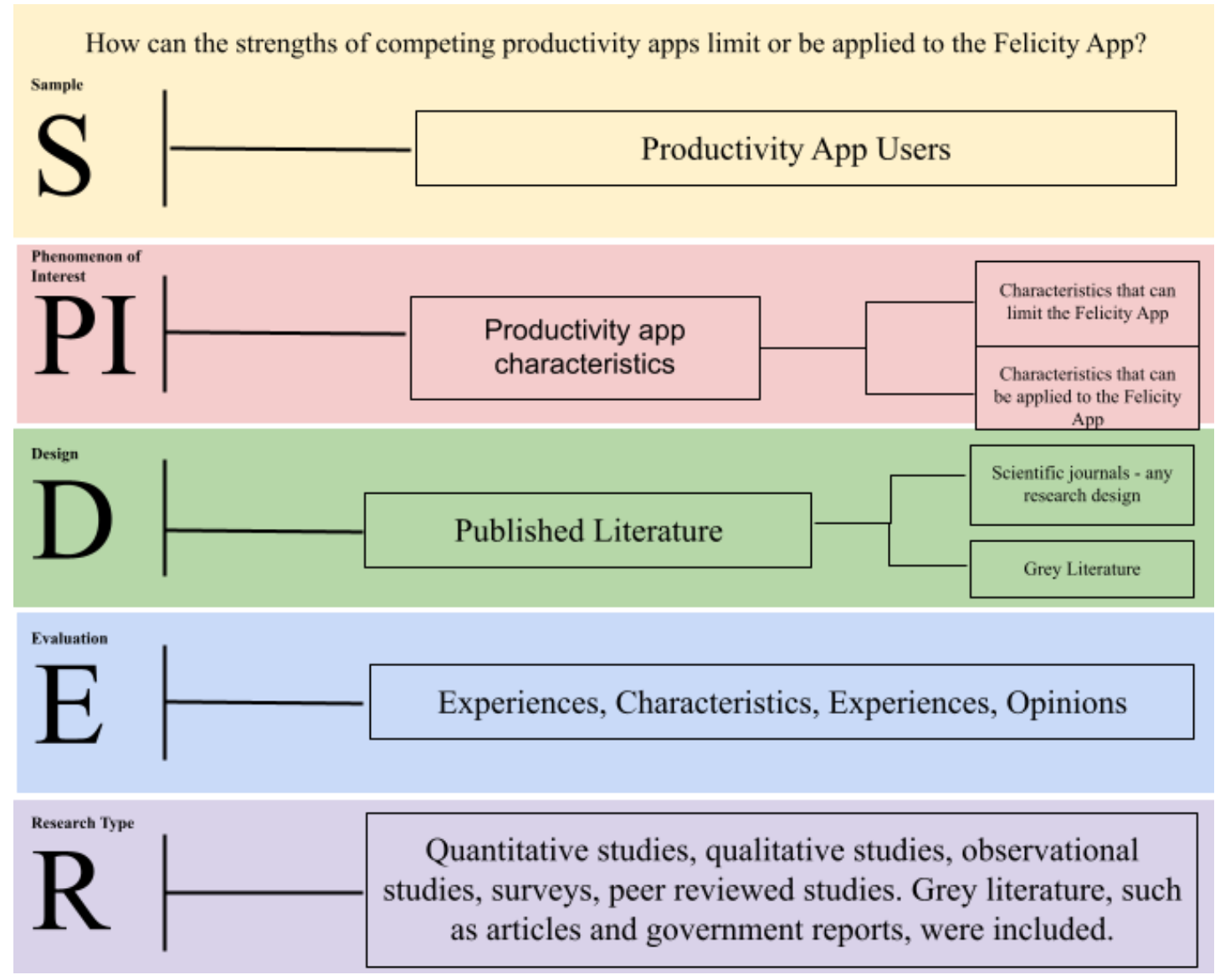

Fig. 1 Structural outline of SPIDER components that will be analyzed in this environmental scan

\section{Data Collection and Abstraction}

The articles that were gathered using the search strategy were put into the program EndNote X8. This was done so that any duplicate articles gathered from multiple sources could be removed. Using the research question, inclusion and exclusion criteria were determined. This was done so that a screening tool could be made. The screening tool, a questionnaire with 10 questions, excluded articles unrelated to the main research question. The screening tool reduced individual biases and provided an objective means of collecting data related to the research question. The articles gathered in the search strategy were screened by 2 authors, DK and RT. DK and RT used the screening tool to screen 218 articles.

\section{Identification of Relevant Studies and Data Extraction}

From June 6, 2021 to June 15, 2021, several databases were used to gather research articles. These databases were Web of Science, ProQuest, and Business Source Premier. Furthermore, the Harvard Business Review magazine was used to determine grey literature articles. 2 screeners (DK and RT) independently screened all articles (from both the databases and from grey literature sources) from June 15, 2021 to July 20, 2021. Then, DK and RT reconciled disagreements in whether an article passed or did not pass the screening tool. In the event that 
DK and RT weren not able to reconcile disagreements, a third author, HD, would resolve the issue. The first round of screening (which involved screening the abstracts of 218 articles) resulted in 42 articles being produced. This round of screening (abstract screening) was done from June 15, 2021 to June 21, 2021. The second round of screening (which involved screening the entire text of the 42 articles that were produced from the first round of screening) produced 15 articles. This round of screening (full-text screening) was done from June 22, 2021 to June 29, 2021. Hand searches were done from June 29, 2021 - July 2, 2021. The first round of hand search screening was done from July 7, 2021 - July 13, 2021, and the second round of hand search screening was done from July 13, 2021 - July 20, 2021. Refer to Appendix 3 for a list of excluded studies.

\section{Data Extraction}

Database search extraction was done by authors JB and DQ independently, followed by reconciliation. Hand search extraction was done by authors KA and DQ independently, followed by reconciliation. The authors determined data such as study design, trend type, participant information, type of data collected, and significance of the trend (see Appendix 4 for Study Characteristics). All authors resolved disagreements during reconciliation. In the case of disagreements that arose, a third author resolved the disagreement.

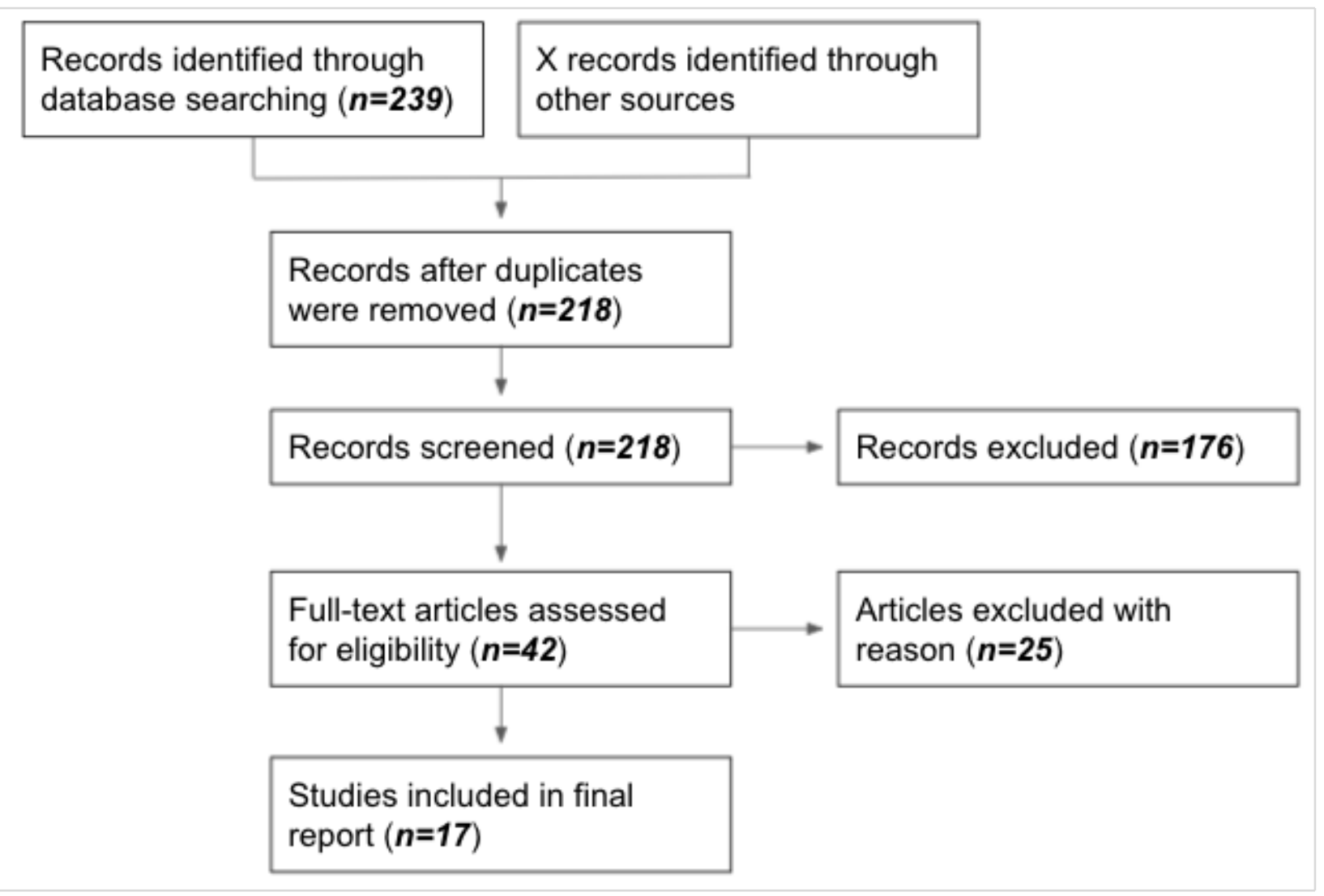

Fig. 2 Structural diagram of the completed screening and study selection processes 


\section{RESULTS}

Study Selection

The study selection and screening process is illustrated in Figure 2. 239 papers were recognized through database searches, including 21 duplicates. After duplicated records were removed only 218 papers remained. Next, 218 articles were selected for abstract screening. Out of the 218 published studies 194 were retrieved from ProQuest, 14 were retrieved from Business Source Premier and 10 articles were retrieved from grey literature. The published and grey literature articles both underwent abstract screening and full-text screening. Only 42 papers were left after abstract screening and 176 papers were excluded. The 42 articles that were left after abstract screening consisted of 28 published articles and 4 grey literature. After full text screening only 17 articles were left, including 13 published articles, 3 grey literature and 1 duplicate paper. When performing hand searches 235 articles were obtained with 176 published articles and 59 grey literature selected throughout the process. After screening the hand searches only 31 articles were finalized. Within the 31 articles were 16 published articles and 15 grey literature.

\section{Study Characteristics.}

This study consists of 35 published articles which includes 16 qualitative, 2 quantitative, 9 voluntary participation examinations, 1 randomized control trial (RCT), 1 semi-structured interview, 2 academic studies, 1 student observations and attitudinal surveys, and 3 studies with unavailable information on the type of study design, duration, and participants involved.

Out of the 35 published studies included, 13 were from the United States of America; 3 from Canada; 4 from the United Kingdom; 3 from Germany; 1 from Israel, Spain and Greece; and 8 from unknown countries.

\section{Findings and Outcomes}

Findings from articles that were not relevant or did not answer the research question were not included. Of the 34 articles extracted only the best 15 were included in Table 1 . Three articles discuss competitors in the market and their features for improving productivity. Seven articles found that mobile-based interventions are effective at improving either overall health or productivity. The last 5 articles provided more information on methods to stay productive along with information that may be applicable to the Felicity App as a mobile-based intervention. The outcome on how the Felicity App would be affected is listed in Table 1.

Table 1 Findings and outcomes of relevant articles

\begin{tabular}{|l|l|l|}
\hline Article & Findings & Outcomes \\
\hline $\begin{array}{l}\text { Humana Launches Mobile App } \\
\text { Designed to Improve Health and } \\
\text { Social Engagement for Employers }\end{array}$ & $\begin{array}{l}\text { A workplace with an } \\
\text { established culture of } \\
\text { wellness leads to }\end{array}$ & $\begin{array}{l}\text { Felicity could implement some } \\
\text { of Goal Guru's features allowing } \\
\text { users to monitor their wellness }\end{array}$ \\
\hline
\end{tabular}




\begin{tabular}{|c|c|c|}
\hline & $\begin{array}{l}\text { increased engagement } \\
\text { and productivity of } \\
\text { employees in company } \\
\text { missions and goals. } \\
\text { Mobile app, Goal } \\
\text { Guru, monitors user's } \\
\text { steps, weight and sleep } \\
\text { along with other } \\
\text { interactive features, } \\
\text { such as allowing users } \\
\text { to interact with each } \\
\text { other through } \\
\text { competitions and } \\
\text { challenges, as a means } \\
\text { of improving overall } \\
\text { health of employees. }\end{array}$ & in order to increase productivity. \\
\hline $\begin{array}{l}\text { ThinkHR Launches Premium HR } \\
\text { Solutions Suite To Give Insurance } \\
\text { Brokers Competitive Edge: } \\
\text { Workplace Pro includes a } \\
\text { comprehensive and flexible } \\
\text { compliance calendar and mobile } \\
\text { app for a seamless experience that } \\
\text { helps employers reduce risk and } \\
\text { improve productivity }\end{array}$ & $\begin{array}{l}\text { Workplace Pro } \\
\text { includes a calendar } \\
\text { directly regulated by } \\
\text { ThinkHR's group of } \\
\text { expert staff attorneys. } \\
\text { Their new mobile app } \\
\text { allows employees } \\
\text { immediate access to } \\
\text { HR questions and } \\
\text { answers. }\end{array}$ & $\begin{array}{l}\text { The Felicity App could include a } \\
\text { moderated Q\&A for users who } \\
\text { require assistance. }\end{array}$ \\
\hline $\begin{array}{l}\text { Top ways to increase } \\
\text { productivity; Maintaining a } \\
\text { healthy balance in life helps } \\
\text { efficiency }\end{array}$ & $\begin{array}{l}\text { The human mind and } \\
\text { brain are not made for } \\
\text { heavy-duty } \\
\text { multitasking. Suggests } \\
\text { keeping track of how } \\
\text { much time you devote } \\
\text { to certain tasks } \\
\text { everyday and } \\
\text { performing the } \\
\text { physical task of jotting } \\
\text { things down. }\end{array}$ & $\begin{array}{l}\text { The Felicity app could } \\
\text { implement a feature for taking } \\
\text { jot notes and a timer to limit the } \\
\text { use of multitasking. }\end{array}$ \\
\hline $\begin{array}{l}\text { Behavior Change Techniques in } \\
\text { mHealth Apps for the Mental and } \\
\text { Physical Health of Employees: } \\
\text { Systematic Assessment }\end{array}$ & $\begin{array}{l}\text { Certain combinations } \\
\text { of BCTs, such as } \\
\text { providing information } \\
\text { on link between } \\
\text { behaviour and health } \\
\text { or follow up prompts, }\end{array}$ & $\begin{array}{l}\text { The Felicity app could } \\
\text { implement features which are } \\
\text { more geared towards long-term } \\
\text { results such as follow-ups. }\end{array}$ \\
\hline
\end{tabular}




\begin{tabular}{|c|c|c|}
\hline & $\begin{array}{l}\text { will have a higher } \\
\text { chance of being more } \\
\text { effective at improving } \\
\text { health behavior. }\end{array}$ & \\
\hline $\begin{array}{l}\text { Top } 10 \text { Apps to Increase Your } \\
\text { Productivity }\end{array}$ & $\begin{array}{l}\text { To increase } \\
\text { productivity } \\
\text { competitors utilize } \\
\text { checklists, email } \\
\text { managers and planners. }\end{array}$ & $\begin{array}{l}\text { The Felicity app could } \\
\text { implement a feature for } \\
\text { checklists or planning to } \\
\text { increase productivity. }\end{array}$ \\
\hline $\begin{array}{l}\text { Match Your Productivity } \\
\text { Approach to the Way You Work }\end{array}$ & $\begin{array}{l}\text { People have different } \\
\text { productivity styles. } \\
\text { Some people prefer } \\
\text { timing how long tasks } \\
\text { take and others prefer } \\
\text { flexibility and variety } \\
\text { in their schedule. }\end{array}$ & $\begin{array}{l}\text { Focusing on one type of } \\
\text { productivity style will limit the } \\
\text { audience the Felicity app } \\
\text { attracts. }\end{array}$ \\
\hline $\begin{array}{l}\text { How Working Parents Can Get } \\
\text { the Most Out of Calendar Apps }\end{array}$ & $\begin{array}{l}\text { Misspent time is a } \\
\text { result of letting others } \\
\text { set your priorities. Set } \\
\text { your priorities, set } \\
\text { limits and practice time } \\
\text { blocking. }\end{array}$ & $\begin{array}{l}\text { A feature which allows users to } \\
\text { practice time blocking could } \\
\text { prove very effective at getting } \\
\text { tasks done. }\end{array}$ \\
\hline $\begin{array}{l}\text { Effectiveness of an Internet- and } \\
\text { App-Based Intervention for } \\
\text { College Students With Elevated } \\
\text { Stress: Randomized Controlled } \\
\text { Trial }\end{array}$ & $\begin{array}{l}\text { Internet- and App- } \\
\text { based interventions } \\
\text { reduce negative } \\
\text { consequences of } \\
\text { college-related stress. }\end{array}$ & $\begin{array}{l}\text { The app can aim to reduce stress } \\
\text { and thus increase productivity. }\end{array}$ \\
\hline $\begin{array}{l}\text { Evaluating online stress } \\
\text { management intervention for } \\
\text { college students }\end{array}$ & $\begin{array}{l}\text { A correlation between } \\
\text { lower levels of } \\
\text { depression, stress and } \\
\text { anxiety have been } \\
\text { found with the element } \\
\text { of control. }\end{array}$ & $\begin{array}{l}\text { The Felicity app should allow } \\
\text { users complete control to reduce } \\
\text { stress and thus increase } \\
\text { productivity. }\end{array}$ \\
\hline $\begin{array}{l}\text { MyStudentBody-Stress: an online } \\
\text { stress management intervention } \\
\text { for college students }\end{array}$ & $\begin{array}{l}\text { Online stress } \\
\text { management } \\
\text { intervention is } \\
\text { effective in increasing } \\
\text { physical activity, } \\
\text { prompting the use of } \\
\text { specific stress }\end{array}$ & $\begin{array}{l}\text { The Felicity app can utilize } \\
\text { stress management methods to } \\
\text { improve the overall health of } \\
\text { users. }\end{array}$ \\
\hline
\end{tabular}




\begin{tabular}{|c|c|c|}
\hline & $\begin{array}{l}\text { management methods } \\
\text { and decreasing overall } \\
\text { anxiety. }\end{array}$ & \\
\hline $\begin{array}{l}\text { The benefit of web- and } \\
\text { computer-based interventions for } \\
\text { stress: a systematic review and } \\
\text { meta-analysis. }\end{array}$ & $\begin{array}{l}\text { Web- and computer- } \\
\text { based interventions are } \\
\text { effective in reducing } \\
\text { stress, depression and } \\
\text { anxiety. Guided } \\
\text { interventions and } \\
\text { interventions lasting } \\
<8 \text { weeks are most } \\
\text { effective. }\end{array}$ & $\begin{array}{l}\text { Interventions in the Felicity app } \\
\text { should be no longer than } 8 \\
\text { weeks and should be guided to } \\
\text { be effective. }\end{array}$ \\
\hline $\begin{array}{l}\text { Patients' experiences in a guided } \\
\text { Internet- and app-based stress } \\
\text { intervention for college students: } \\
\text { a qualitative study. }\end{array}$ & $\begin{array}{l}\text { Patients wanted more } \\
\text { individualization/contr } \\
\text { ol, information } \\
\text { regarding their } \\
\text { situation, more specific } \\
\text { to their situation } \\
\text { related-support, shorter } \\
\text { session lengths and } \\
\text { less frequent } \\
\text { reminders. }\end{array}$ & $\begin{array}{l}\text { The Felicity app can provide } \\
\text { background information and } \\
\text { certain behaviour-health links, } \\
\text { and provide the option for } \\
\text { reminders and session length } \\
\text { preference. }\end{array}$ \\
\hline $\begin{array}{l}\text { A randomised controlled trial of a } \\
\text { brief online mindfulness-based } \\
\text { intervention. }\end{array}$ & $\begin{array}{l}\text { Online intervention } \\
\text { was effective in } \\
\text { significantly increasing } \\
\text { mindfulness skills and } \\
\text { decreasing perceived } \\
\text { stress, depression and } \\
\text { anxiety symptoms. }\end{array}$ & $\begin{array}{l}\text { By practicing mindfulness, the } \\
\text { user's overall wellbeing can } \\
\text { improve. }\end{array}$ \\
\hline $\begin{array}{l}\text { Randomized controlled trial } \\
\text { evaluating the effectiveness of a } \\
\text { web-based stress management } \\
\text { program among community } \\
\text { college students }\end{array}$ & $\begin{array}{l}\text { Participation in the } \\
\text { web-based intervention } \\
\text { resulted in participants } \\
\text { having increased } \\
\text { control and decreased } \\
\text { depression, anxiety, } \\
\text { perceived stress and } \\
\text { symptoms. }\end{array}$ & $\begin{array}{l}\text { Giving the user more control } \\
\text { over what they can do on the } \\
\text { app will lead to better health } \\
\text { outcomes. }\end{array}$ \\
\hline $\begin{array}{l}\text { 'Does digital game-based learning } \\
\text { improve student time-on-task } \\
\text { behavior and engagement in } \\
\text { comparison to alternative }\end{array}$ & $\begin{array}{l}\text { Trials showed that with } \\
\text { DGBL there were } \\
\text { higher levels of } \\
\text { enjoyment along with } \\
\text { student time-on-task }\end{array}$ & $\begin{array}{l}\text { Positive reinforcement of being } \\
\text { productive such as } \\
\text { implementing games or } \\
\text { challenges could increase } \\
\text { enjoyment of users utilizing the }\end{array}$ \\
\hline
\end{tabular}




\begin{tabular}{|l|l|l|}
\hline instructional strategies?' & $\begin{array}{l}\text { behaviour and } \\
\text { engagement. }\end{array}$ & Felicity app. \\
\hline
\end{tabular}

\section{DISCUSSION}

\section{Introduction}

This environmental scan aimed to determine how the strengths and weaknesses of competing productivity apps could improve the Felicity App. This was done by analyzing over 200 scholarly articles which presented similar goals. However, the resources used were not uniform and articles used included, but were not limited to, qualitative data, quantitative data, surveys, and randomized control trials. This analysis culminated in a selection of key articles $(n=15)$ that would help address the main goal of the environmental scan. Presented below are the takeaways from the key articles and how they could be used to improve the Felicity App.

\section{Strengths of Other Apps}

With the advancement of new health-monitoring technologies that can measure physiological characteristics in recent years, tracking wellbeing has been easier for individuals. From tracking the number of steps walked daily to tracking heartbeat, innovative technologies allow for easy measuring of physiological characteristics. This strength has been utilized by other wellbeing applications, such as Humana, which monitor's their employees' physiological characteristics to encourage overall health and wellness [6]. Additionally, it is imperative that users focus on the app. Many other apps have utilized features that prevent multitasking to elicit complete focus from users. This includes keeping track of time spent on everyday tasks and physically jotting information down to reinforce it.

While improving outcomes often occurs with wellbeing apps, the persistence of these outcomes is difficult to maintain. To combat this, applications utilize features such as follow up prompts to ensure results are maintained in the long term.

Another important finding regarding control posits that control in one's life is associated with lower levels of anxiety and stress. This is why many online stress management systems for college students encourage complete user control of the application. This increases the overall wellbeing of individuals, thus producing improved productivity outcomes.

While it's important to improve the content of an application, app developers must consider the app experience itself (such as navigating the app, adjusting settings, etc.). The user experience is often regarded as the backbone of an app. A significant step apps have taken to improve the user experience is including a direct method of contacting a support team. This way, users have immediate access to answers and can continue enjoying the content of the app. 


\section{How Strengths Would Be Integrated Into The Felicity App}

The Felicity App can integrate monitoring users physical health and wellness in addition to mental wellbeing to ensure maximal productivity and overall well being [6]. This can be done by including a habit tracker in the app whereby users can track their exercise, sleep and diet, as well as receive reminders from the app to continue practicing these habits.

Through this systematic review, it has been found that users engage more with productivity apps when there is a competitive or collectivist element [22]. Therefore, the Felicity App should integrate a way through which individuals can interact and compete with friends and mutuals in order to optimize user engagement and intervention compliance. This can be done through incorporating a feature that allows users to add their contacts into the application as well as adding a scoreboard feature. This scoreboard will show users their "friends" progress as well as their own, if they choose to share this information publicly. As such, monitoring their own progress alongside their acquaintances' progress will motivate individuals to continue completing interventions to increase their score, allowing them to obtain the best outcome from the app.

In addition to the collectivist approach, positive reinforcement was shown as a crucial element to maintain user engagement [22]. Although the Felicity App already incorporates this element through the implementation of growing avatars, this feature can be further developed. For example, an avatar shop can be introduced where new items become available to users as they follow interventions and complete interventions. Alternatively, users can obtain different badges as they reach new milestones. An important, and simpler, feature that can be implemented is a statistics page where users can see which aspects of their mental wellbeing and mindfulness journey they are excelling at and which aspects they need to strengthen [6]. This will allow users to fully take advantage of all the interventions available to them.

Finally, the importance of user control when following interventions was found to be crucial to increase user engagement as it decreases stress levels [5]. This is a crucial aspect that can be further enhanced through the Felicity App by allowing users to customize their interventions based on their goals for the day or week. In addition, the app can offer different variations of the same intervention based on the amount of time the user wants to spend on the interventions [4]. This will allow users increased flexibility and control, optimizing their engagement with the app.

\section{Weaknesses of Other Apps}

Most calendar applications follow the same format whereby users input events, deadlines, meetings, and appointments into their calendar. However, this has been found to be less tactical and effective. Instead, it has been proposed that calendar apps should show users where they are spending their time and use this information to suggest a schedule for the user as well as implement reminders. 
Vogel et al. found that gamification was not preferred as a teaching method when delivered through a computer-based format [24]. Instead, students benefited and accepted the gamification method when used by teachers whereas a traditional teaching method was preferred when using a computer.

\section{Possible Similar Weaknesses in the Felicity App}

The calendar app in the Felicity App allows users to type in entries into the calendar of meetings with people, upcoming assignments, appointments, etcetera. However, it has been reported that this traditional use of a calendar is less effective as it should also allow users to view where and how they are spending their time while also providing reminders to complete tasks or follow ups [21]. This can be integrated in the Felicity App by including an end-of-week statistics page which shows the user where/how their time was spent by breaking it into different categories (eg. 'work', 'assignment completion', 'exercise', 'hobbies', etc). By adding this feature to the calendar, the Felicity App will allow users to be proactive about their time management and take full advantage of the app.

Another limitation that applies to the Felicity App is that studies have shown that the use of gamification in an educational setting was less desirable for students when delivered through a computer [24]. It was reported that students preferred a regular educational format when using computer-based learning. This weakness is similar to the Felicity App as gamification is used as an intervention to enhance users' wellbeing and motivation. Although the Felicity App will remain a mobile application, this limitation can be avoided through the use of a realistic avatar and voice system that can guide the users through the gamification interventions. Therefore, this guided format will keep users interested and increase their likelihood to enjoy and complete this intervention.

\section{Strength and Limitations}

This environmental scan aimed to search the literature to determine the strengths and areas of improvements of the Felicity App. This was done to answer the question "How can the strengths of competing productivity apps limit or be applied to the Felicity App?". Although there are several strengths to this systematic review, there are important limitations to consider. The research question was answered through use of only three databases: ProQuest, Web of Science, and Business Premier. As a result, the systematic review does not fully explore all threats and opportunities in the productivity app market. Similarly, a lot of the sources examined were more focused on workplace or group settings which also narrows the scope of the review to this specific setting.

\section{CONCLUSION}

The use of mental health applications is on the rise. It is imperative that these mental health applications utilize effective interventions and resources to promote the best outcome for users. 
By determining strategies, interventions, and resources used by similar applications, mental health applications significantly increase their chance at promoting the best outcome for users. It is for this reason that an environmental scan was conducted to determine how competing mental health applications optimize their interface, provide effective interventions for users, and ultimately help users as much as possible. It was determined that several strengths and weaknesses of other applications can be integrated into the Felicity App to improve outcomes for users. These results will be used to market the Felicity App to audiences upon release in late 2021.

\section{REFERENCES}


[1] Are productivity apps more hype than help? (2015, October 19). BBC News. https://www.bbc.com/news/business-34506590

[2] Colonial Life study: Stressed workers costing employers billions - weekly. (n.d.). Colonial Life. Retrieved August 26, 2021, from

https://www.coloniallife.com/about/newsroom/2019/march/stressed-workers-costing-employersbillions

[3] Delmonte, M. M. (1984). Meditation Practice as Related to Occupational Stress, Health and Productivity. Perceptual and Motor Skills, 59(2), 581-582.

https://doi.org/10.2466/pms.1984.59.2.581

[4] Fleischmann, R. J., Harrer, M., Zarski, A.-C., Baumeister, H., Lehr, D., \& Ebert, D. D. (2018). Patients' experiences in a guided Internet- and App-based stress intervention for college students: A qualitative study. Internet Interventions, 12, 130-140.

https://doi.org/10.1016/j.invent.2017.12.001

[5] Frazier, P., Meredith, L., Greer, C., Paulsen, J. A., Howard, K., Dietz, L. R., \& Qin, K. (2015). Randomized controlled trial evaluating the effectiveness of a web-based stress management program among community college students. Anxiety, Stress, \& Coping, 28(5), 576-586. https://doi.org/10.1080/10615806.2014.987666

[6] Humana Launches Mobile App Designed to Improve Health and Social Engagement for Employers. (2016, November 22).

https://www.businesswire.com/news/home/20161122005969/en/Humana-Launches-MobileApp-Designed-to-Improve-Health-and-Social-Engagement-for-Employers

[7] Killinger, B. (2018, July 17). A Distracted Workplace Costs Far More Than Productivity Loss. Chief Learning Officer - CLO Media. https://www.chieflearningofficer.com/2018/07/17/adistracted-workplace-costs-far-more-than-productivity-loss/

[8] Lindsay, E. K., Young, S., Smyth, J. M., Brown, K. W., \& Creswell, J. D. (2018). Acceptance lowers stress reactivity: Dismantling mindfulness training in a randomized controlled trial. Psychoneuroendocrinology, 87, 63-73. https://doi.org/10.1016/j.psyneuen.2017.09.015

[9] Mixed Methods: Integrating Quantitative and Qualitative Data Collection and Analysis While Studying Patient-Centered Medical Home Models | PCMH Resource Center. (n.d.). Retrieved August 26, 2021, from https://pcmh.ahrq.gov/page/mixed-methods-integratingquantitative-and-qualitative-data-collection-and-analysis-while

[20] Mobile App Download \& Usage Report 2019: Stats You Must Know. (n.d.). Retrieved August 26, 2021, from https://www.goodfirms.co/resources/app-downloadusage-statistics-to-know 
[21] Newton, C. (2016, August 31). Sunrise is dead, and so is the dream of an excellent calendar app. The Verge. https://www.theverge.com/2016/8/31/12632532/sunrise-dead-why-calendarapps-suck

[22] Schaaf, R. (2012). Does digital game-based learning improve student time-on-task behavior and engagement in comparison to alternative instructional strategies? The Canadian Journal of Action Research, 13(1), 50-64. https://doi.org/10.33524/cjar.v13i1.30

[23] M, K., NC, R., Isaac, O., Harish, K. S., Iqbal, M. I., \& Srivvastava, K. (2021). STUDY ON EFFECT OF MEDITATION ON INDIVIDUAL'S PERFORMANCE AT WORKPLACE.

International Journal of Management (IJM), 12(1), 379-389.

https://doi.org/10.34218/IJM.12.1.2021.033

[24] Vogel, J. J., Vogel, D. S., Cannon-Bowers, J., Bowers, C. A., Muse, K., \& Wright, M. (2006). Computer Gaming and Interactive Simulations for Learning: A Meta-Analysis. Journal of Educational Computing Research, 34(3), 229-243.

\section{DECLARATIONS}

\section{Funding:}

N/A 


\section{Conflicts of interest/Competing interests:}

The authors declared no potential conflicts of interest with respect to the research, authorship, and/or publication of this article.

\section{Availability of data and material:}

Available upon request.

\section{Code availability:}

N/A

\section{Authors' contributions:}

HD devised and supervised the environmental scan. KA conceptualized the environmental scan and designed the protocol. KA, JB, and DQ conducted the database search. RT and DZ completed preliminary and full-text screenings, JB and DQ completed the database extraction and analysis. KA and DQ completed the handsearch extraction and analysis. KA created figures and computed numerical data. KA, JB, DQ, RT, and DZ equally wrote the manuscript. All authors reviewed the final manuscript.

\section{Appendix 1}

\section{Database Searches}

Date occurred (June 6, 2021 to June 15, 2021)

\begin{tabular}{|l|l|l|}
\hline Database & Search & Results \\
\hline ProQuest & $\begin{array}{l}\text { (productivity app*) AND } \\
(\text { mobile*) AND ((enhance*) } \\
\text { OR (improve*) OR } \\
(\text { increase*) }\end{array}$ & 305 \\
\hline Business Source Premier & $\begin{array}{l}\text { (productivity app*) AND } \\
\text { (mobile*) AND (strength*) }\end{array}$ & 30 \\
\hline Web of Science & $\begin{array}{l}\text { (productivity AND app*) } \\
\text { AND (strength*) AND } \\
\text { (mobile*) }\end{array}$ & 39 \\
\hline
\end{tabular}

\section{Appendix 2}

\section{Grey Literature Searches}


Date occurred (June 15, 2021 to June 22, 2021)

\begin{tabular}{|l|l|l|}
\hline Database & Search & Results \\
\hline Harvard Business Review & Productivity app* & 17 \\
\hline
\end{tabular}

\section{Appendix 3}

\section{List of Excluded Files from Full Text Screening}

\begin{tabular}{|l|l|}
\hline Author/Journal & Title \\
\hline M2 Presswire & There's a (business) app for that \\
\hline Ginger \& Any.do & $\begin{array}{l}\text { Ginger and Any.do Partner to Boost Productivity While Messaging: } \\
\text { Any.do, the award winning task management app, partners with } \\
\text { Ginger to increase productivity while chatting on mobile }\end{array}$ \\
\hline Wilson, H.J. & Imagining Productivity Apps for the Apple Watch \\
\hline Good Technology & $\begin{array}{l}\text { Good Technology Delivers Increased Developer Support and } \\
\text { Ecosystem Integration for Good Dynamics Secure Mobility } \\
\text { Platform: Ensures native, HTML5, and hybrid apps are secured and } \\
\text { enterprise-ready }\end{array}$ \\
\hline Realwire & $\begin{array}{l}\text { Infostrada Sports and Roambi release iPhone and iPad apps to } \\
\text { answer your London Games questions }\end{array}$ \\
\hline PR Newswire & $\begin{array}{l}\text { Trimble Introduces its FieldMaster Technician App to Enhance } \\
\text { Mobile Workforce Productivity }\end{array}$ \\
\hline PR Newswire & $\begin{array}{l}\text { Snapsheet Moves to Intacct to Modernize Financial Processes and } \\
\text { Support Future Growth: BT Partners Helps Auto Claims Mobile } \\
\text { App Provider Adopt Cloud ERP to Empower Decision-Makers and } \\
\text { Increase Productivity }\end{array}$ \\
\hline PR Newswire & $\begin{array}{l}\text { ExpertusONE Uses New Mobile Technology for Unprecedented } \\
\text { LMS App Functionality: Innovative Presence Sensing, mobile } \\
\text { reporting and contact share features dramatically improve learning } \\
\text { adoption and productivity }\end{array}$ \\
\hline $\begin{array}{l}\text { News Bites - } \\
\text { Electronics }\end{array}$ & $\begin{array}{l}\text { Trimble Announces New Field Service Management Features to } \\
\text { Improve Mobile Workforce Productivity }\end{array}$ \\
\hline $\begin{array}{l}\text { Trimble"s New Construction Logistics Mobile App Provides Real- } \\
\text { Time, Visual Data to Improve Operations }\end{array}$ \\
\hline
\end{tabular}




\begin{tabular}{|c|c|}
\hline PR Newswire & hopTo Inc. Announces First Quarter 2015 Highlights and Results \\
\hline Productivity Software & IMS HEALTH APPSCRIPT OFFERS MEDISAFE TO PATIENTS \\
\hline M2 Presswire & $\begin{array}{l}\text { TeamUltra launches TeamStore: an App Store for ServiceNow } \\
\text { applications; ServiceNow Preferred Solutions Partner creates } \\
\text { TeamStore for complementary Service Management apps, products } \\
\text { and solutions }\end{array}$ \\
\hline M2 Presswire & $\begin{array}{l}\text { TeamUltra launches TeamStore: an App Store for ServiceNow } \\
\text { applications }\end{array}$ \\
\hline PR Newswire & $\begin{array}{l}\text { NexTraq(R) Introduces NexTraq View(TM): Company Launches } \\
\text { Powerful App with New Features to Enhance Real-Time Visibility } \\
\text { of Fleet Assets and Provide the Power of Real-Time Productivity }\end{array}$ \\
\hline PharmaBiz & $\begin{array}{l}\text { Aprima partners with DocBuddy mobile workflow app to enhance } \\
\text { physician productivity }\end{array}$ \\
\hline PR Newswire & $\begin{array}{l}\text { Aprima Medical Software Partners with DocBuddy Mobile } \\
\text { Workflow App to Enhance Physician Productivity: Medical } \\
\text { providers report saving more than } 45 \text { minutes per day }\end{array}$ \\
\hline Business Wire & $\begin{array}{l}\text { Microland Launches Global Mobile App for Its Digital Workforce } \\
\text { to Enhance Business Productivity and Collaboration }\end{array}$ \\
\hline $\begin{array}{l}\text { ICT Monitor } \\
\text { Worldwide }\end{array}$ & $\begin{array}{l}\text { Sapho enables more apps on IBM Domino with its Micro App } \\
\text { Platform }\end{array}$ \\
\hline $\begin{array}{l}\text { ICT Monitor } \\
\text { Worldwide }\end{array}$ & SmartLinx Enhances Mobile App to Increase Employee Productivity \\
\hline Business Wire & $\begin{array}{l}\text { Kyield Offers Breakthrough Semantic Solution for the Challenges } \\
\text { Facing Modern Organizations }\end{array}$ \\
\hline BizWest & 11 startups complete Techstars experience \\
\hline $\begin{array}{l}\text { Scientific Bulletin } \\
\text { "Mircea cel Batran" } \\
\text { Naval Academy }\end{array}$ & BYOD IN LARGE ORGANIZATIONS \\
\hline $\begin{array}{l}\text { Business Process } \\
\text { Management Journal }\end{array}$ & An evaluation of the value stream mapping tool \\
\hline $\begin{array}{l}\text { Material Handling } \\
\text { Product News }\end{array}$ & Track assets with automatic monitoring system, app \\
\hline Overman, D. & Product Guide 2021: Practice Management \\
\hline
\end{tabular}




\begin{tabular}{|c|c|}
\hline Eisenberg, D & Stigma and help seeking for mental health among college students. \\
\hline $\begin{array}{l}\text { Batterham, P. J., \& } \\
\text { Calear, A. L. }\end{array}$ & $\begin{array}{l}\text { Preferences for Internet-based mental health interventions in an } \\
\text { adult online sample: findings from an online community survey }\end{array}$ \\
\hline Sander, L., et al. & $\begin{array}{l}\text { Effectiveness of Internet-based interventions for the prevention of } \\
\text { mental disorders: a systematic review and meta-analysis }\end{array}$ \\
\hline $\begin{array}{l}\text { Deutsches Register } \\
\text { Klinischer Studien }\end{array}$ & $\begin{array}{l}\text { Online based self-help stress management program for students with } \\
\text { feedback on demand }\end{array}$ \\
\hline Zarski, A. C., et al. & $\begin{array}{l}\text { Adherence to Internet-based mobile-supported stress management: a } \\
\text { pooled analysis of individual participant data from three randomized } \\
\text { controlled trials }\end{array}$ \\
\hline TotalMobile & $\begin{array}{l}\text { TotalMobile Launches Optimise, Designed To Further Empower A } \\
\text { Mobile Workforce }\end{array}$ \\
\hline $\begin{array}{l}\text { Van den Heuvel, S. G., } \\
\text { et al. }\end{array}$ & Productivity loss at work; health related and work-related factors \\
\hline Anderson, I., et al. & $\begin{array}{l}\text { Shakra: tracking and sharing daily activity levels with unaugmented } \\
\text { mobile phones }\end{array}$ \\
\hline $\begin{array}{l}\text { Christmann, C. A., et } \\
\text { al. }\end{array}$ & $\begin{array}{l}\text { Stress Management Apps With Regard to Emotion-Focused Coping } \\
\text { and Behavior Change Techniques: A Content Analysis }\end{array}$ \\
\hline Lyons, E. J., et al. & $\begin{array}{l}\text { Behavior change techniques implemented in electronic lifestyle } \\
\text { activity monitors: a systematic content analysis }\end{array}$ \\
\hline Morford, Z.H. & $\begin{array}{l}\text { Procrastination and Goal-setting Behaviors in the College } \\
\text { Population: an Exploratory Study }\end{array}$ \\
\hline Rettig, H. & $\begin{array}{l}\text { The } 7 \text { Secrets of the Prolific: The Definitive Guide to Overcoming } \\
\text { Procrastination, Perfectionism, and Writer's Block }\end{array}$ \\
\hline
\end{tabular}

\section{Appendix 4}

\section{Study Characteristics}

\begin{tabular}{|l|l|l|l|l|}
\hline $\begin{array}{l}\text { Author, Date, } \\
\text { Title of Study }\end{array}$ & Country & $\begin{array}{l}\text { Study design, } \\
\text { duration, and } \\
\text { participants }\end{array}$ & Type of data & $\begin{array}{l}\text { Identified } \\
\text { Threats/Opportunities/Data - } \\
\text { Outcome }\end{array}$ \\
\hline Ross & US & Survey, 200 HR & Qualitative & Humana found that \\
\hline
\end{tabular}




\begin{tabular}{|c|c|c|c|c|}
\hline $\begin{array}{l}\text { McLerran/New } \\
\text { York Business } \\
\text { Wire, } 2016 \\
\text { November 22, } \\
\text { Humana } \\
\text { Launches Mobile } \\
\text { App Designed to } \\
\text { Improve Health } \\
\text { and Social } \\
\text { Engagement for } \\
\text { Employers }\end{array}$ & & $\begin{array}{l}\text { executives/mana } \\
\text { gers and } 500 \text { full } \\
\text { time employees }\end{array}$ & $\begin{array}{l}\text { description } \\
\text { through } \\
\text { survey }\end{array}$ & $\begin{array}{l}\text { employers who establish a } \\
\text { defined workplace culture of } \\
\text { wellness can achieve } \\
\text { widespread positive impact } \\
\text { on the health and } \\
\text { productivity of their } \\
\text { employees while increasing } \\
\text { engagement in company } \\
\text { mission and goals. Goal } \\
\text { Guru allows users to } \\
\text { participate in competition } \\
\text { and engage with each other } \\
\text { through wellness tracking, } \\
\text { challenges and } 24 / 7 \\
\text { interaction with a digital } \\
\text { coach. } \\
\text { Opportunity: If launched } \\
\text { among felicity members, } \\
\text { could run as a trial - benefit } \\
\text { is that our app you don't } \\
\text { have to pay for whereas in } \\
\text { this app they paid for it }\end{array}$ \\
\hline $\begin{array}{l}\text { Anne Baker, } \\
2016 \text { March 16, } \\
\text { ThinkHR } \\
\text { Launches } \\
\text { Premium HR } \\
\text { Solutions Suite } \\
\text { To Give } \\
\text { Insurance } \\
\text { Brokers } \\
\text { Competitive } \\
\text { Edge: Workplace } \\
\text { Pro includes a } \\
\text { comprehensive } \\
\text { and flexible } \\
\text { compliance } \\
\text { calendar and } \\
\text { mobile app for a }\end{array}$ & US & $\mathrm{n} / \mathrm{a}$ & $\begin{array}{l}\text { Qualitative } \\
\text { description }\end{array}$ & $\begin{array}{l}\text { Workplace Pro includes a } \\
\text { compliance calendar that is } \\
\text { automatically populated } \\
\text { with compliance deadlines, } \\
\text { and a mobile app that } \\
\text { enables employers to get } \\
\text { immediate answers to } \\
\text { critical HR questions }\end{array}$ \\
\hline
\end{tabular}




\begin{tabular}{|c|c|c|c|c|}
\hline $\begin{array}{l}\text { seamless } \\
\text { experience that } \\
\text { helps employers } \\
\text { reduce risk and } \\
\text { improve } \\
\text { productivity }\end{array}$ & & & & \\
\hline $\begin{array}{l}2017 \text { May 13, } \\
\text { Top ways to } \\
\text { increase } \\
\text { productivity; } \\
\text { Maintaining a } \\
\text { healthy balance } \\
\text { in life helps } \\
\text { efficiency }\end{array}$ & Canada & $\mathrm{n} / \mathrm{a}$ & $\begin{array}{l}\text { Qualitative } \\
\text { description }\end{array}$ & $\begin{array}{l}\text { Research has revealed that } \\
\text { the mind and brain were not } \\
\text { designed for heavy-duty } \\
\text { multitasking. Calculate how } \\
\text { much time you're devoting } \\
\text { to certain parts of your } \\
\text { workday. The physical task } \\
\text { of writing things down and } \\
\text { crossing items off the list } \\
\text { one-by-one can help you sail } \\
\text { through tasks effectively. If } \\
\text { you're a mobile person, jot } \\
\text { the list down on the notes } \\
\text { function of a smartphone or } \\
\text { use a task app that syncs } \\
\text { with calendar functions. }\end{array}$ \\
\hline $\begin{array}{l}\text { de Korte et al., } \\
2018 \text { October } 3 \text {, } \\
\text { Behavior Change } \\
\text { Techniques in } \\
\text { mHealth Apps } \\
\text { for the Mental } \\
\text { and Physical } \\
\text { Health of } \\
\text { Employees: } \\
\text { Systematic } \\
\text { Assessment }\end{array}$ & Canada & $\begin{array}{l}\text { Comparative } \\
\text { assessment of } 45 \\
\text { apps aimed at } \\
\text { reducing } \\
\text { physical, and } \\
\text { psychosocial } \\
\text { risks at work. } \\
\text { December } 2014 \\
\text { - April } 2015\end{array}$ & $\begin{array}{l}\text { Comparative } \\
\text { qualitative } \\
\text { study }\end{array}$ & $\begin{array}{l}\text { Top } 3 \text { most used BCT's: } \\
\text { Provide information on } \\
\text { behaviour-health link, } \\
\text { provide instruction, time } \\
\text { management. Top } 3 \text { least } \\
\text { utilized BCT's: Stress } \\
\text { management, prompt } \\
\text { identification as a role } \\
\text { model, agree on behavioural } \\
\text { contract. Dusseldorp et al } \\
\text { concluded from their meta- } \\
\text { analysis that specific } \\
\text { combinations of BCTs } \\
\text { increase the likelihood of } \\
\text { achieving change in health } \\
\text { behavior, whereas other }\end{array}$ \\
\hline
\end{tabular}




\begin{tabular}{|c|c|c|c|c|}
\hline & & & & $\begin{array}{l}\text { combinations decrease the } \\
\text { possibility. BCT's: Relapse } \\
\text { prevention and follow up } \\
\text { prompts may be of value } \\
\text { long term. } \\
\text { Opportunity: from their } \\
\text { suggestion to increase } \\
\text { potential and effectiveness, } \\
\text { a collaboration between app } \\
\text { developers, health behavior } \\
\text { change professionals, } \\
\text { experts on physical and } \\
\text { mental health, and end-users } \\
\text { is suggested. }\end{array}$ \\
\hline $\begin{array}{l}\text { Li et al., } 2018, \\
\text { Can a Game- } \\
\text { based } \\
\text { Productivity } \\
\text { Tool Improve } \\
\text { Procrastination? }\end{array}$ & Greece & $\begin{array}{l}\text { Test Run \& } \\
\text { Technology } \\
\text { acceptance } \\
\text { model } \\
\text { questionnaire, } \\
\text { tested by } 81 \\
\text { users }\end{array}$ & $\begin{array}{l}\text { Qualitative } \\
\text { description } \\
\text { through } \\
\text { questionnair } \\
\text { e }\end{array}$ & $\begin{array}{l}\text { procrastination factors: task } \\
\text { aversiveness, time of reward } \\
\text { and punishment, } \\
\text { impulsiveness and } \\
\text { conscientiousness } \\
\text { Opportunity: "They gave } \\
\text { specific definitions for the } \\
\text { different terms that they } \\
\text { used while addressing } \\
\text { theories - in their conclusion } \\
\text { they suggested that the } \\
\text { mechanic of converting real } \\
\text { world tasks to story goals } \\
\text { could be refined. How to } \\
\text { accurately monitor the user's } \\
\text { progress hasn't been } \\
\text { addressed in this study yet. } \\
\text { In addition, the behavior } \\
\text { changes of using the } \\
\text { proposed framework could } \\
\text { be discussed. }\end{array}$ \\
\hline $\begin{array}{l}\text { Jason Shueh, } \\
2014 \text { May 23, } \\
\text { Top } 10 \text { Apps to }\end{array}$ & US & $\mathrm{n} / \mathrm{a}$ & $\begin{array}{l}\text { Qualitative } \\
\text { description }\end{array}$ & $\begin{array}{l}\text { Competitors: Clear - } \\
\text { Checklists, CloudMagic - } \\
\text { Email manager, Sunrise }\end{array}$ \\
\hline
\end{tabular}




\begin{tabular}{|c|c|c|c|c|}
\hline $\begin{array}{l}\text { Increase Your } \\
\text { Productivity }\end{array}$ & & & & $\begin{array}{l}\text { Calendar - Calendar/planner, } \\
\text { Trello - Project Planning } \\
\text { and collaboration }\end{array}$ \\
\hline $\begin{array}{l}\text { Carson Tate, } \\
2015 \text { January 27, } \\
\text { Match Your } \\
\text { Productivity } \\
\text { Approach to the } \\
\text { Way You Work }\end{array}$ & $n / a$ & $\mathrm{n} / \mathrm{a}$ & $\begin{array}{l}\text { Qualitative } \\
\text { description }\end{array}$ & $\begin{array}{l}\text { Personal Productivity } \\
\text { Styles: Prioritizers and } \\
\text { Planners - may time how } \\
\text { long it takes to complete } \\
\text { tasks in order to better plan, } \\
\text { Visualizers - energized by } \\
\text { task variety and schedule } \\
\text { flexibility, Arrangers - } \\
\text { looser time management } \\
\text { policy }\end{array}$ \\
\hline $\begin{array}{l}\text { Alexandra } \\
\text { Samuel, } 2020 \\
\text { January } 8, \text { Create } \\
\text { a Productivity } \\
\text { Workflow That } \\
\text { Works for You }\end{array}$ & $\mathrm{n} / \mathrm{a}$ & $\mathrm{n} / \mathrm{a}$ & $\mathrm{n} / \mathrm{a}$ & $\mathrm{n} / \mathrm{a}$ \\
\hline $\begin{array}{l}\text { John Hall, } 2019 \\
\text { August 8, How } \\
\text { Working Parents } \\
\text { Can Get the } \\
\text { Most Out of } \\
\text { Calendar Apps }\end{array}$ & $\mathrm{n} / \mathrm{a}$ & $\mathrm{n} / \mathrm{a}$ & $\begin{array}{l}\text { Qualitative } \\
\text { description }\end{array}$ & $\begin{array}{l}\text { Calendar Use - Outline your } \\
\text { priorities first. The biggest } \\
\text { culprit behind misspent } \\
\text { time? Letting others set your } \\
\text { priorities. -Set limits. Time } \\
\text { blocking (or timeboxing) }\end{array}$ \\
\hline $\begin{array}{l}\text { Katherine } \\
\text { Borthwick, } 2014 \\
\text { December 2, } \\
\text { Flowfinity } \\
\text { Launches New } \\
\text { App Editor for } \\
\text { Faster Enterprise } \\
\text { Mobile App } \\
\text { Creation: }\end{array}$ & Canada & $\mathrm{n} / \mathrm{a}$ & $\begin{array}{l}\text { Qualitative } \\
\text { description }\end{array}$ & $\begin{array}{l}\text { Flowfinity Actions } 8.0 \text {, the } \\
\text { new app editor makes it } \\
\text { easier to navigate through } \\
\text { app fields, layouts, and } \\
\text { pages, enabling apps to be } \\
\text { customized with fewer } \\
\text { clicks. Not much data }\end{array}$ \\
\hline
\end{tabular}




\begin{tabular}{|c|c|c|c|c|}
\hline $\begin{array}{l}\text { Flowfinity } \\
\text { Actions } 8.0 \\
\text { makes } \\
\text { programming- } \\
\text { free app } \\
\text { configuration } \\
\text { more intuitive } \\
\text { and efficient }\end{array}$ & & & & \\
\hline $\begin{array}{l}\text { Sarum PR, } 2015 \\
\text { June 11, } \\
\text { TotalMobile } \\
\text { Launches } \\
\text { Optimise, } \\
\text { Designed To } \\
\text { Further } \\
\text { Empower A } \\
\text { Mobile } \\
\text { Workforce; A } \\
\text { Resource } \\
\text { Management } \\
\text { Solution } \\
\text { Developed To } \\
\text { Manage A More } \\
\text { Efficient And } \\
\text { Productive } \\
\text { Workforce }\end{array}$ & UK & $\mathrm{n} / \mathrm{a}$ & $\begin{array}{l}\text { Qualitative } \\
\text { description }\end{array}$ & $\begin{array}{l}\text { Optimise provides total } \\
\text { flexibility around how } \\
\text { schedules are created - } \\
\text { providing an important } \\
\text { element of control } \\
\text { Threat: Another app that } \\
\text { poses a possible threat - } \\
\text { TotalMobile is a 30-year-old } \\
\text { software provider which } \\
\text { specialises in innovative } \\
\text { mobile-working solutions } \\
\text { for public and private sector } \\
\text { field workers. Its solutions } \\
\text { are especially popular in } \\
\text { health, social care and local } \\
\text { government, being ideally } \\
\text { suited to frontline workers } \\
\text { who spend much of their } \\
\text { time completing tasks in the } \\
\text { community. The fast- } \\
\text { growing company has over } \\
\text { 25,000 users around the } \\
\text { world, with customers } \\
\text { spanning the UK, Ireland, } \\
\text { Europe and North America. }\end{array}$ \\
\hline $\begin{array}{l}2016 \text { April 11, } \\
\text { Crestron Tackles } \\
\text { \$37 Billion }\end{array}$ & US & $\mathrm{n} / \mathrm{a}$ & $\begin{array}{l}\text { Qualitative } \\
\text { description }\end{array}$ & $\begin{array}{l}\text { Crestron Pinpoint }{ }^{\mathrm{TM}} \text { lets } \\
\text { employees take control of } \\
\text { every aspect of their }\end{array}$ \\
\hline
\end{tabular}




\begin{tabular}{|c|c|c|c|c|}
\hline $\begin{array}{l}\text { Challenge: The } \\
\text { Cost and } \\
\text { Frustration of } \\
\text { Bad Meetings: } \\
\text { New } \\
\text { PinPoint(TM) } \\
\text { Mobile App and } \\
\text { Crestron } \\
\text { Fusion(R) Cloud } \\
\text { Platform } \\
\text { Remove } \\
\text { Bottlenecks and } \\
\text { Improve } \\
\text { Workforce } \\
\text { Productivity }\end{array}$ & & & & $\begin{array}{l}\text { meetings, including } \\
\text { scheduling, setup, execution } \\
\text { and completion. With an } \\
\text { awareness of an employee's } \\
\text { location, it identifies nearby } \\
\text { meeting rooms with the } \\
\text { right technology and devices } \\
\text { to meet their needs, and } \\
\text { ensures a personalized, } \\
\text { automated meeting } \\
\text { experience. }\end{array}$ \\
\hline $\begin{array}{l}\text { Harsh Agrawal, } \\
2020 \text { August 21, } \\
8 \text { Tips for } \\
\text { Bloggers To } \\
\text { Increase \&amp; } \\
\text { Maintain } \\
\text { Productivity }\end{array}$ & $\mathrm{n} / \mathrm{a}$ & $\mathrm{n} / \mathrm{a}$ & $\begin{array}{l}\text { Qualitative } \\
\text { description }\end{array}$ & $\begin{array}{l}\text { Tips on improving } \\
\text { productivity: Time- } \\
\text { management, To-do list, } \\
\text { Disabling notifications, } \\
\text { Pomodoro Technique }\end{array}$ \\
\hline $\begin{array}{l}\text { Jason Ankeny, } \\
2013 \text { June 21, } \\
\text { Tempo AI raises } \\
\text { \$10M to enhance } \\
\text { iOS smart } \\
\text { calendar app }\end{array}$ & $\mathrm{n} / \mathrm{a}$ & $\mathrm{n} / \mathrm{a}$ & $\begin{array}{l}\text { Qualitative } \\
\text { description }\end{array}$ & $\begin{array}{l}\text { Tempo AI leverages } \\
\text { artificial intelligence } \\
\text { research and semantic } \\
\text { technology to automatically } \\
\text { connect the user's upcoming } \\
\text { schedule of meetings and } \\
\text { events to their emails, } \\
\text { contacts and location data, } \\
\text { enabling one-tap access to } \\
\text { details like conference } \\
\text { agendas, phone numbers, } \\
\text { driving directions and travel } \\
\text { itineraries. Users can also } \\
\text { browse attendees' LinkedIn } \\
\text { profiles, view foursquare } \\
\text { and Yelp reviews and send a }\end{array}$ \\
\hline
\end{tabular}




\begin{tabular}{|c|c|c|c|c|}
\hline & & & & $\begin{array}{l}\text { pre-populated "running late" } \\
\text { email or text. }\end{array}$ \\
\hline $\begin{array}{l}\text { Harrer et al., } \\
2018 \text { April 23, } \\
\text { Effectiveness of } \\
\text { an Internet- and } \\
\text { App-Based } \\
\text { Intervention for } \\
\text { College Students } \\
\text { With Elevated } \\
\text { Stress: } \\
\text { Randomized } \\
\text { Controlled Trial }\end{array}$ & $\mathrm{n} / \mathrm{a}$ & $\begin{array}{l}\text { 2-armed } \\
\text { randomized } \\
\text { controlled trial } \\
\text { was conducted } \\
\text { with } 150 \\
\text { (college } \\
\text { students) } \\
\text { participants. } \\
\text { Self-report data } \\
\text { were collected } \\
\text { using a Web- } \\
\text { based } \\
\text { assessment tool }\end{array}$ & $\begin{array}{l}\text { Quantitative } \\
\text { randomized } \\
\text { control trial }\end{array}$ & $\begin{array}{l}\text { internet- and mobile-based } \\
\text { interventions could be an } \\
\text { acceptable, effective, and } \\
\text { potentially cost-effective } \\
\text { approach to reduce the } \\
\text { negative consequences } \\
\text { associated with college- } \\
\text { related stress. }\end{array}$ \\
\hline $\begin{array}{l}\text { Hintz S, Frazier } \\
\text { PA, Meredith L, } \\
2015 \text { April, } \\
\text { Evaluating } \\
\text { online stress } \\
\text { management } \\
\text { intervention for } \\
\text { college students }\end{array}$ & US & $\begin{array}{l}\text { Three armed } \\
\text { randomized } \\
\text { control trial, } \\
\text { psychology } \\
\text { students ( } \mathrm{n}= \\
\text { 292), } 3 \text { week } \\
\text { duration }\end{array}$ & $\begin{array}{l}\text { Participation } \\
\text { in } \\
\text { interventions } \\
\text {, scores on } \\
\text { the } \\
\text { Perceived } \\
\text { Control Over } \\
\text { Stressful } \\
\text { Events Scale }\end{array}$ & $\begin{array}{l}\text { Present control has been } \\
\text { found to be associated with } \\
\text { a range of positive outcomes } \\
\text { including lower levels of } \\
\text { depression, stress and } \\
\text { anxiety }\end{array}$ \\
\hline $\begin{array}{l}\text { Chiauzzi E, } \\
\text { Brevard J, Thum } \\
\text { C, Decembrele } \\
\text { S, Lord S, } 2008 \\
\text { August, } \\
\text { MyStudentBody- } \\
\text { Stress: an online } \\
\text { stress } \\
\text { management } \\
\text { intervention for } \\
\text { college students }\end{array}$ & US & $\begin{array}{l}\text { Three armed } \\
\text { randomized } \\
\text { control trial, } \\
\text { college students } \\
\text { at } 6 \text { U.S. } \\
\text { colleges }(n=240)\end{array}$ & $\begin{array}{l}\text { Participation } \\
\text { in } \\
\text { interventions } \\
\text {, scores on } \\
\text { the } \\
\text { Perceived } \\
\text { Stress Scale }\end{array}$ & $\begin{array}{l}\text { MyStudentBody-Stress } \\
\text { (online stress management } \\
\text { intervention) participants } \\
\text { were more likely to increase } \\
\text { weekly physical activity, use } \\
\text { specific stress management } \\
\text { methods, and exhibit } \\
\text { decreased anxiety and } \\
\text { family problems }\end{array}$ \\
\hline
\end{tabular}




\begin{tabular}{|c|c|c|c|c|}
\hline $\begin{array}{l}\text { Ebert DD, Lehr } \\
\text { D, Smit F, Zarski } \\
\text { AC, Riper H, } \\
\text { Heber E, } \\
\text { Cuijpers P, } \\
\text { Berking M, } 2014 \\
\text { January - } \\
\text { August, Efficacy } \\
\text { and cost- } \\
\text { effectiveness of } \\
\text { minimal guided } \\
\text { and unguided } \\
\text { internet-based } \\
\text { mobile supported } \\
\text { stress- } \\
\text { management in } \\
\text { employees with } \\
\text { occupational } \\
\text { stress: a three- } \\
\text { armed } \\
\text { randomised } \\
\text { controlled trial }\end{array}$ & Germany & $\begin{array}{l}\text { Three armed } \\
\text { randomized } \\
\text { control trial }(\mathrm{n}= \\
408), 6 \text { month } \\
\text { duration }\end{array}$ & $\begin{array}{l}\text { Participation } \\
\text { in } \\
\text { interventions } \\
\text {, scores on } \\
\text { the } \\
\text { Perceived } \\
\text { Stress Scale }\end{array}$ & $\begin{array}{l}\text { effective low-threshold } \\
\text { interventions are needed that } \\
\text { are accessible for as many } \\
\text { people as possible }\end{array}$ \\
\hline $\begin{array}{l}\text { Heber E, Ebert } \\
\text { DD, Lehr D, } \\
\text { Cuijpers P, } \\
\text { Berking M, } \\
\text { Nobis S, Riper } \\
\text { H, } 2017 \\
\text { February,The } \\
\text { benefit of web- } \\
\text { and computer- } \\
\text { based } \\
\text { interventions for } \\
\text { stress: a } \\
\text { systematic } \\
\text { review and meta- } \\
\text { analysis. }\end{array}$ & Germany & $\begin{array}{l}\text { Meta-analysis } \\
\text { with } 26 \\
\text { comparisons (n } \\
=4226 \text { ), RCT's } \\
\text { with participants } \\
>18 \text { years from } \\
1990 \text { - May } \\
2016 \text { (articles) }\end{array}$ & $\begin{array}{l}\text { Randomized } \\
\text { control trials }\end{array}$ & $\begin{array}{l}\text { Web- and computer-based } \\
\text { stress-management } \\
\text { interventions can be } \\
\text { effective in reducing stress, } \\
\text { depression, and anxiety and } \\
\text { maintain those effects for up } \\
\text { to } 6 \text { months. Second, } \\
\text { interventions using TWC } \\
\text { and CBT interventions as a } \\
\text { theoretical basis proved } \\
\text { moderately effective in } \\
\text { reducing stress. Third, short } \\
\text { and medium interventions } \\
\text { (up to } 8 \text { weeks) are more } \\
\text { effective than long } \\
\text { interventions (9 weeks and } \\
\text { longer). Fourth, guided }\end{array}$ \\
\hline
\end{tabular}




\begin{tabular}{|c|c|c|c|c|}
\hline & & & & $\begin{array}{l}\text { interventions yielded a } \\
\text { greater effect size for } \\
\text { reduction of stress than } \\
\text { unguided interventions. }\end{array}$ \\
\hline $\begin{array}{l}\text { Fleischmann RJ, } \\
\text { Harrer M, Zarski } \\
\text { AC, Baumeister } \\
\text { H, Lehr D, Ebert } \\
\text { DD, 2018 June, } \\
\text { Patients' } \\
\text { experiences in a } \\
\text { guided Internet- } \\
\text { and app-based } \\
\text { stress } \\
\text { intervention for } \\
\text { college students: } \\
\text { a qualitative } \\
\text { study. }\end{array}$ & Germany & $\begin{array}{l}\text { Two-armed } \\
\text { randomized } \\
\text { control trial, } 150 \\
\text { participants (>= } \\
18 \text { yrs, German } \\
\text { speaking } \\
\text { university } \\
\text { students), } 3 \\
\text { month duration. } \\
\text { (sessions were } 1 \\
\text { hour and } \\
\text { interview was } \\
45 \text { minutes) }\end{array}$ & $\begin{array}{l}\text { Semi- } \\
\text { structured } \\
\text { interviews }\end{array}$ & $\begin{array}{l}\text { Expressed the need for more } \\
\text { individualization, more } \\
\text { content-related support, } \\
\text { more background } \\
\text { information, better } \\
\text { understanding of their } \\
\text { situation. Session length and } \\
\text { frequency of reminder } \\
\text { constitute the feeling of } \\
\text { overwhelmedness caused by } \\
\text { treatment. }\end{array}$ \\
\hline $\begin{array}{l}\text { Cavanagh K, } \\
\text { Strauss C, } \\
\text { Cicconi F, } \\
\text { Griffiths N, } \\
\text { Wyper A, Jones } \\
\text { F, } 2013 \\
\text { September, A } \\
\text { randomised } \\
\text { controlled trial of } \\
\text { a brief online } \\
\text { mindfulness- } \\
\text { based } \\
\text { intervention. }\end{array}$ & UK & $\begin{array}{l}\text { Online two } \\
\text { armed } \\
\text { randomized } \\
\text { control trial, } 155 \\
\text { students, } 2 \text { week } \\
\text { duration }\end{array}$ & $\begin{array}{l}\text { Participation } \\
\text { in } \\
\text { interventions } \\
\text {, scores on } \\
\text { measures of } \\
\text { mindfulness, } \\
\text { perceived } \\
\text { stress, } \\
\text { perseverative } \\
\text { thinking and } \\
\text { anxiety/depr } \\
\text { ession } \\
\text { symptoms }\end{array}$ & $\begin{array}{l}\text { Participants in the } \\
\text { intervention had significant } \\
\text { improvement in mindfulness } \\
\text { skills, perceived stress and } \\
\text { anxiety/depression } \\
\text { symptoms. }\end{array}$ \\
\hline $\begin{array}{l}\text { Frazier P, } \\
\text { Meredith L, } \\
\text { Greer C, Paulsen } \\
\text { JA, Howard K, } \\
\text { Dietz LR, Qin K, }\end{array}$ & US & $\begin{array}{l}\text { Two-armed } \\
\text { randomized } \\
\text { control trial, } 257 \\
\text { students, } 3 \text { week } \\
\text { duration }\end{array}$ & $\begin{array}{l}\text { Participation } \\
\text { in } \\
\text { interventions } \\
\text {, self-report } \\
\text { measures of }\end{array}$ & $\begin{array}{l}\text { Intervention group reported } \\
\text { increased control and } \\
\text { decreased perceived stress, } \\
\text { stress symptoms, depression } \\
\text { and anxiety. }\end{array}$ \\
\hline
\end{tabular}




\begin{tabular}{|c|c|c|c|c|}
\hline $\begin{array}{l}2014 \text { December } \\
22, \text { Randomized } \\
\text { controlled trial } \\
\text { evaluating the } \\
\text { effectiveness of a } \\
\text { web-based stress } \\
\text { management } \\
\text { program among } \\
\text { community } \\
\text { college students }\end{array}$ & & & $\begin{array}{l}\text { perceived } \\
\text { stress, stress } \\
\text { symptoms, } \\
\text { depression, } \\
\text { and anxiety }\end{array}$ & \\
\hline $\begin{array}{l}\text { Rai D, Lin CW, } \\
\text { Ierlan MT, 2016, } \\
\text { The Influence of } \\
\text { Scheduling Style } \\
\text { on Assortment } \\
\text { Size }\end{array}$ & US & $\begin{array}{l}\text { Survey, } \mathrm{n}=82 \\
\text { Amazon } \\
\text { mechanical Turk } \\
\text { participants. } \\
\text { Study } 2 \text { - } \\
\text { manipulating } \\
\text { instead of } \\
\text { measuring } \\
\text { scheduling } \\
\text { styles, survey, n } \\
=69 \text { Mturk, } \\
56 \% \text { female, } \\
\text { mean age = } 41\end{array}$ & $\begin{array}{l}\text { Participation } \\
\text { in a survey }\end{array}$ & $\begin{array}{l}\text { Scheduling style influences } \\
\text { consumers' assortment size } \\
\text { preferences, clock timers } \\
\text { focus on feasibility } \\
\text { preferring small } \\
\text { assortments, and event } \\
\text { timers focus on desirability } \\
\text { considerations preferring } \\
\text { large assortments. }\end{array}$ \\
\hline $\begin{array}{l}\text { Mark E, } 2013 \\
\text { July - August, - } \\
\text { Gamification, A } \\
\text { Tool for } \\
\text { Effective Patient } \\
\text { Retention }\end{array}$ & UK & $\mathrm{n} / \mathrm{a}$ & $\begin{array}{l}\text { Qualitative } \\
\text { description }\end{array}$ & $\begin{array}{l}\text { Gamification is the natural } \\
\text { add-in as it helps build a } \\
\text { framework around reminder/ } \\
\text { calendar functionality }\end{array}$ \\
\hline $\begin{array}{l}\text { Vogel, J.J., } \\
\text { Vogel, D.S., } \\
\text { Cannon-Bowers, } \\
\text { J., Bowers, C.A., } \\
\text { Muse, K. and } \\
\text { Wright, M, } \\
\text { (2006 April), } \\
\text { 'Computer }\end{array}$ & US & Meta-analysis & $\begin{array}{l}\text { Academic } \\
\text { studies }\end{array}$ & $\begin{array}{l}\text { Males show no preference } \\
\text { while females show } \\
\text { preference for the game and } \\
\text { interactive simulation } \\
\text { programs - when controlled } \\
\text { by teachers there was no } \\
\text { advantage. When dictated } \\
\text { by a computer there was }\end{array}$ \\
\hline
\end{tabular}




\begin{tabular}{|c|c|c|c|c|}
\hline $\begin{array}{l}\text { gaming and } \\
\text { interactive } \\
\text { simulations for } \\
\text { learning: a meta- } \\
\text { analysis' }\end{array}$ & & & & $\begin{array}{l}\text { preference for the traditional } \\
\text { teaching method. }\end{array}$ \\
\hline $\begin{array}{l}\text { Schaaf, R. } \\
\text { (2012). 'Does } \\
\text { digital game- } \\
\text { based learning } \\
\text { improve student } \\
\text { time-on-task } \\
\text { behavior and } \\
\text { engagement in } \\
\text { comparison to } \\
\text { alternative } \\
\text { instructional } \\
\text { strategies?' }\end{array}$ & US & $\begin{array}{l}\text { Randomized } \\
\text { control trial, } \\
\text { elementary } \\
\text { school students } \\
\text { age } 8-10\end{array}$ & $\begin{array}{l}\text { Student } \\
\text { observations } \\
\text { and } \\
\text { attitudinal } \\
\text { surveys }\end{array}$ & $\begin{array}{l}\text { 7/8 trials produced higher } \\
\text { student table observations } \\
\text { averages for DGBL, and } 6 / 8 \\
\text { trials showed higher student } \\
\text { survey average in level of } \\
\text { enjoyment while } \\
\text { experiencing DGBL. }\end{array}$ \\
\hline $\begin{array}{l}2000 \text { August, } \\
\text { Stop } \\
\text { procrastination } \\
\text { now! }\end{array}$ & US & $\mathrm{n} / \mathrm{a}$ & $\begin{array}{l}\text { Qualitative } \\
\text { description }\end{array}$ & $\begin{array}{l}\text { Do the worst task first, } \\
\text { "you'll be in a better state of } \\
\text { mind to complete the rest". } \\
\text { Take } 10 \text { - a few minutes is } \\
\text { enough to get yourself into } \\
\text { the flow of a project. Plan } \\
\text { ahead. Break it down } \\
\text { (smaller steps). }\end{array}$ \\
\hline $\begin{array}{l}\text { Hen M, Goroshit } \\
\text { M, 2020, The } \\
\text { effects of } \\
\text { decisional and } \\
\text { academic } \\
\text { procrastination } \\
\text { on students' } \\
\text { feelings toward } \\
\text { academic } \\
\text { procrastination }\end{array}$ & Israel & $\begin{array}{l}\text { Survey, } 373 \\
\text { undergraduate } \\
\text { social sciences } \\
\text { students }\end{array}$ & $\begin{array}{l}\text { Participation } \\
\text { in a survey, } \\
\text { scores on } \\
\text { Decisional } \\
\text { Procrastinati } \\
\text { on } \\
\text { Questionnair } \\
\text { e and } \\
\text { Academic } \\
\text { Procrastinati } \\
\text { on Scale - } \\
\text { Student }\end{array}$ & $\begin{array}{l}\text { decisional procrastinators } \\
\text { experience discomfort } \\
\text { associated with } \\
\text { procrastination, academic } \\
\text { procrastinators want to } \\
\text { change their procrastination } \\
\text { habits but do not report } \\
\text { feelings of discomfort }\end{array}$ \\
\hline
\end{tabular}




\begin{tabular}{|c|c|c|c|c|}
\hline & & & Form & \\
\hline $\begin{array}{l}\text { Alsawaier RS, } \\
2018 \text { January } 2 \text {, } \\
\text { The Effect of } \\
\text { Gamification on } \\
\text { Motivation and } \\
\text { Engagement }\end{array}$ & US & $\begin{array}{l}\text { Literature } \\
\text { review }\end{array}$ & $\begin{array}{l}\text { Academic } \\
\text { studies }\end{array}$ & $\begin{array}{l}\text { More research needs to be } \\
\text { done }\end{array}$ \\
\hline $\begin{array}{l}\text { Newton C, } 2016 \\
\text { August } 31 \text {, } \\
\text { Sunrise is dead, } \\
\text { and so is the } \\
\text { dream of an } \\
\text { excellent } \\
\text { calendar app }\end{array}$ & US & $\mathrm{n} / \mathrm{a}$ & $\begin{array}{l}\text { Qualitative } \\
\text { description }\end{array}$ & $\begin{array}{l}\text { Calendar apps face } \\
\text { challenges that prevent them } \\
\text { from improving. Type in } \\
\text { nearly any combination of } \\
\text { who you're meeting with, } \\
\text { and when, and where, and } \\
\text { Fantastical turns it into a } \\
\text { calendar entry. calendar } \\
\text { should be tactical, finding } \\
\text { me time for my stated } \\
\text { priorities. It should offer } \\
\text { analytics on the time I spend } \\
\text { on meetings, and with } \\
\text { whom, and follow up with } \\
\text { me on any action items. }\end{array}$ \\
\hline $\begin{array}{l}\text { Dìaz-Morales JF, } \\
\text { Ferrari JR, } \\
\text { Cohen JR, } 2008 \\
\text { July, Indecision } \\
\text { and avoidant } \\
\text { procrastination: } \\
\text { The role of } \\
\text { morningness- } \\
\text { eveningness and } \\
\text { time perspective } \\
\text { in chronic delay } \\
\text { lifestyles }\end{array}$ & Spain & $\begin{array}{l}\text { Survey, } 509 \\
\text { adults mean age } \\
=49.78\end{array}$ & $\begin{array}{l}\text { Participation } \\
\text { in three } \\
\text { psychometri } \\
\text { c scales }\end{array}$ & $\begin{array}{l}\text { Avoidant procrastination } \\
\text { related to low future time } \\
\text { orientation and low } \\
\text { morningness, whereas } \\
\text { indecision related to both (a) } \\
\text { high negative and high } \\
\text { positive past orientations } \\
\text { and (b) low present- } \\
\text { hedonistic and low future } \\
\text { time orientations }\end{array}$ \\
\hline 2016 May 18 & UK & $\mathrm{n} / \mathrm{a}$ & Qualitative & Users are able to specify \\
\hline
\end{tabular}




\begin{tabular}{|c|c|c|c|c|}
\hline $\begin{array}{l}\text { Shift Calendar } \\
\text { app }\end{array}$ & & & description & $\begin{array}{l}\text { what type of shift they work } \\
\text { and on what days by tapping } \\
\text { on calendar dates. They are } \\
\text { then given an option of day } \\
\text { or night to choose. There are } \\
\text { even options to add notes on } \\
\text { each day. }\end{array}$ \\
\hline $\begin{array}{l}\text { Streif JD, } 2013 \\
\text { March, } \\
\text { Questions to Ask } \\
\text { before Using } \\
\text { Mobile Devices } \\
\text { and Mobile } \\
\text { Applications for } \\
\text { Business }\end{array}$ & n/a & $\mathrm{n} / \mathrm{a}$ & $\mathrm{n} / \mathrm{a}$ & $\mathrm{n} / \mathrm{a}$ \\
\hline $\begin{array}{l}2014 \text { November } \\
\text { 20, Aroga } \\
\text { Technologies } \\
\text { Updates on } \\
\text { Vizzeco \& LB } \\
\text { Systems } \\
\text { Research Inc. } \\
\text { Partnership and } \\
\text { Global Google } \\
\text { Reseller Rights }\end{array}$ & $\mathrm{n} / \mathrm{a}$ & $\mathrm{n} / \mathrm{a}$ & $\mathrm{n} / \mathrm{a}$ & $\mathrm{n} / \mathrm{a}$ \\
\hline
\end{tabular}

